\title{
TINGKAT PEMAHAMAN ARTI LEKSIKAL PADA LEKSEM YANG BERKONSEP ABSTRAK DAN EMOSI OLEH PENYANDANG TUNARUNGU \\ ${ }^{1 *}$ Alies P. Lintangsari, ${ }^{2}$ Wahyu Widodo \\ ${ }^{1,2}$ Pendidikan Bahasa dan Sastra Inggris, Fakultas Ilmu Budaya, Universitas Brawijaya, Malang, Indonesia’
}

\begin{abstract}
Deaf students find some difficulties mastering the language, especially understanding the Lexeme which has a concept of abstract and Emotion. This is because the deaf rely heavily on references in understanding the meaning of the word. This aims of the study is to determine (1) how the level of understanding of deaf to the Lexeme as a concept of emotion and abstract, (2) Does the background of deaf students (Senior high school or disable Senior high school) play a role in shaping the understanding of abstract and emotional meaning?. Data collection is done by holding a written test that contains the lexeme concept of abstract and emotion with reference and without reference (picture). Analysis is done by considering two things, namely the understanding of deaf to the meaning of Lexeme and the accuracy of the context of the use of Lexeme in the sentence. The results showed that the word abstract of reference is not very influential on the understanding of Deaf, while the Lexeme of emotional references have an effect on helping deaf understand the meaning of lexeme.
\end{abstract}

Keywords: Level of Understanding, Lexeme Meaning, Abstract Lexeme and Emotions, Deaf

\section{Latar Belakang Riset}

Tunarungu menggunakan bahasa isyarat (sign language) atau bahasa bibir (oral) untuk berkomunikasi dengan sesama tunarungu maupun dengan orang normal (hearing). Bahasa isyarat menggunakan tangan, jari, dan ekspresi wajah untuk membentuk kata dan kalimat. Selain itu, mereka juga menggunakan gerak bibir (oral) untuk menyusun kata nonisyarat. Orang normal (hearing) akan mudah membaca gerak bibir yang 'dilafalkan' secara patah-patah oleh tunarungu daripada menggunakan bahasa isyarat. Bahasa isyarat dan oral (gerak bibir) merupakan upaya tunarungu untuk menyusun 'bahasa' agar mereka mampu berkomunikasi tanpa hambatan dengan orang normal (hearing). Upaya ini menunjukkan bahwa tunarungu mempunyai piranti pemerolehan bahasa (Language Acquisition Device) yang terdapat dalam benak dirinya atau dalam perkakas mentalnya (faculty

* Corresponding author: Alies P. Lintangsari alieslintang@gmail.com

Published online at http://IJDS.ub.ac.id

Copyright ( 2017PSLD UB Publishing. All Rights Reserved of the mind), tetapi mereka mempunyai hambatan wicara sehingga 'bahasa mereka' tidak mampu dicerna dengan baik oleh orang normal. Jadi, apa yang dialami oleh tunarungu bukan disebabkan oleh disfungsi motoris, tetapi pada ketidakmampuan mereka untuk mengakses tatabahasa dengan benar (Dardjowidjojo, 2009:222).

Penelitian yang dilakukan oleh Lintangsari (2014) tentang "Identifikasi Kesalahan Mahasiswa Tunarungu dalam Pembelajaran Bahasa Tulis" menemukan bahwa kecenderungan kesalahan yang dilakukan oleh mahasiswa Tunarungu adalah pada tataran sintaksis.

Menilik pelbagai kesalahan pada ranah sintaksis tersebut, ada kemungkinan ketidaksepahaman arti leksikal, arti yang umum dipahami orang normal, juga dialami oleh tunarungu. Hal ini menandakan arti penting bahwa kesalahan pada ranah sintaksis juga menjalar pada ranah semantik. Penelitian ini juga menelisik apakah kemampuan menulis mahasiswa tunarungu di Universitas Brawijaya yang bervariasi itu dimungkinkan karena asal sekolah yang berbeda. Perbedaan kompetensi berbahasa tersebut, kemungkinan, didasarkan pada latar asal sekolah mereka yang berbeda, 
yakni asal sekolah SMA/SMK/MA Inklusi dan SMA/SMK/MA-LB.

Permasalahan mendasar itu ialah pada ranah semantik, khususnya arti leksikal yang dikuasai oleh tunarungu. Bagaimana konsepsi kata dipahami oleh orang tunarungu ?. Dengan kata lain, bagaimana arti leksikal dipahami dalam benak orang tunarungu? Ada dugaan bahwa arti leksem yang dipahami oleh orang normal tidak sebangun dengan pemahaman tunarungu. Ada dugaan kuat bahwa kemungkinan kesalahan selama ini terjadi disebabkan oleh persepsi mental tunarungu terhadap realitas berbeda dengan orang normal. Bangun persepsi orang normal dan orang tunarungu berbeda, meskipun pada satu realitasmaujud yang sama. Hal ini disebabkan karena bahasa orang normal didominasi tanda yang arbitrer (kesewenangan antara tanda-maujud dan lambang), sedangkan bahasa isyarat didominasi tanda yang bersifat ikonik (ada relasi antara simbol dan tanda-maujud). Kata adalah pelambangan dari dunia realitas-yangmaujud. Hal ini diperkuat oleh Kadarisman (2009:89) menyatakan bahwa "yang kita sebut realitas pada hakikatnya lebih merupakan "realitas mental" daripada realitas obyektif di luar pikiran kita". Realitas yang terindra oleh tunarungu kemudian dipersepsikan dalam pikiran mereka, lalu mereka akan menyusun tanda (bahasa isyarat). Tanda-isyarat tersebut dibentuk atas kemiripan (keserupaan) benda yang terindra. Misalnya bahasa isyarat Australia untuk kata Rumah seperti contoh di bawah ini yang sangat mewakili bentuk rumah pada umumnya.

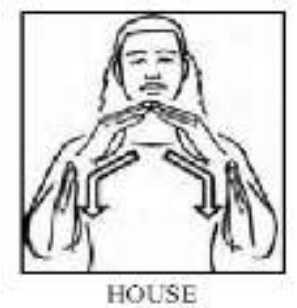

Gambar 1.

Bahasa Isyarat Australia untuk "Rumah"

(Johnston \& Schembri, 2007)

Deskripsi di atas memberi gambaran bahwa tanda-isyarat berkaitan erat dengan realitas yang maujud. Permasalahan kemudian yang muncul bagaimana orang tunarungu menangkap kata yang berkonsep abstrak (misalnya damai, kerukunan, dan kedamaian), dan emosi (senang, sedih, dan marah). Leksem-leksem tersebut tidak mempunyai referensi langsung dengan objek yang terindra. Kata emosi misalnya bagaimana fitur emotif dalam kata 'sedih' dan 'kecewa' dipahami dalam benak orang tunarungu. Ringkasnya, dalam kata abstrak (konsep) bertalian dengan penjelasan dari kegunaan dan pertalian kata tersebut. Pada kata emosi bagaimana sesuatu yang tan-maujud dipersepsikan dalam benak tunarungu

Untuk menjawab pertanyaan di atas disusunlah seperangkat instrumen penelitian yang berisi daftar leksem yang berkonsep emosi dan abstrak. Penyusunan dan pemilihan leksem tersebut dipilih secara acak dan leksem tersebut tidak berlaku khusus pada bidang keilmuan tertentu. Setelah perangkat tersebut disusun, tunarungu menguraikan dan mendeskripsikan bagaimana leksem tersebut dipahami dalam benak mereka. Kemudian dari pemahaman yang diuraikan tersebut digunakan dalam menyusun kalimat. Hal ini digunakan untuk menghadirkan konteks dalam leksem yang dipahami oleh tunarungu.

\section{Rumusan Masalah}

1. Bagaimanakah tingkat pemahaman tunarungu terhadap leksem yang berkonsep emosi dan abstrak ?

2. Apakah latar belakang pendidikan,SMA dan SMA LB, mereka berperan dalam memahami arti abstrak dan emosi ?

\section{Tinjauan Pustaka}

Penelitian yang dilakukan oleh Johnston \& Schembri (2007) bahwa pemaknaan tunarungu terhadap item leksikal (lexical's item) sangat bergantung pada acuan (referent). Pada kajiannya yang meneliti Bahasa Isyarat Australia (Auslan), menemukan bahwa hampir sebagian besar kosa-isyarat dalam bahasa isyarat Australia memiliki acuan langsung (direct referent) dengan makna isyaratnya. Acuan memainkan peran penting untuk memaknai kosa-isyarat, tetapi tidak semua kosa-isyarat memiliki acuan langsung dengan maknanya sehingga menyulitkan proses pemaknaan. Acuan sangat berperan penting bagi orang normal untuk memahami kosaisyarat dan begitu pun sebaliknya, acuan juga memainkan peran penting bagi tunarungu untuk memahami sebuah konsep kata dalam Bahasa 
Indonesia. Kesimpulan awal yang dapat diambil dari penelitian tersebut adalah bahwa tunarungu akan lebih mudah memahami konsep kata dalam bahasa Indonesia yang memiliki acuan langung dengan isyaratnya, sedangkan untuk memahami konsep kata bahasa Indonesia yang tidak memiliki acuan langsung dengan isyaratnya, tunarungu akan mengalami kesulitan untuk memahami maknanya.

\section{Metodologi Penelitian}

Penelitian ini menggunakan metode kualitatif deskriptif yang bertujuan untuk memberikan jawaban atas rumusan masalah yang telah dipaparkan di atas. Metode penelitian ini terdiri dari penjelasan tentang informan penelitian, tahapan penelitian, instrumen penelitian, pengumpulan data, dan analisis data sebagaimana dijelaskan berikut ini

\subsection{Informan Penelitian}

Informan penelitian dalam penelitian ini adalah mahasiswa tunarungu yang berkuliah di Universitas Brawijaya Malang. Informan penelitian terdiri dari 14 mahasiswa tunarungu dengan latar belakang keilmuan yang berbedabeda dan berasal dari Fakultas/Program Studi yang berbeda-beda. Informan penelitian dibagi dalam dua kelompok. Kelompok 1 adalah mahasiswa tunarungu dengan latar belakang pendidikan SMA/SMK berjumlah 7 orang. Kelompok 2 adalah mahasiswa tunarungu dengan latar belakang pendidikan SMALB (SMA Luar Biasa) berjumlah 7 orang. Pengelompokan tersebut bertujuan untuk mengetahui seberapa jauh latar belakang pendidikan menengah atas memberikan pengaruh terhadap penguasaan bahasa anak tunarungu. Penelitian dilaksanakan di kantor Pusat Studi dan Layanan Disabilitas Universitas Brawijaya pada tanggal 11 Agustus 2014 pukul 10.00 sampai dengan pukul 14.30 WIB.

\subsection{Instrumen Penelitian}

Instrumen penelitian dalam penelitian ini terdiri dari dua jenis. Instrumen penelitian yang pertama digunakan untuk mengumpulkan data, instrumen tersebut berupa soal yang berisi leksem-leksem yang berkonsep abstrak dan emosi. Soal terdiri dari dua jenis, yaitu soal tanpa gambar dan soal yang disertai gambar sebagai acuan. Hal ini bertujuan untuk mengetahui seberapa jauh peran gambar (acuan) untuk membantu informan dalam memaknai leksem-leksem yang berkonsep abstrak dan emosi tersebut. Keseluruhan soal berjumlah 40 nomor yang terdiri dari 10 soal leksem berkonsep abstrak tanpa gambar, 10 soal leksem berkonsep abstrak dengan gambar, 10 soal leksem berkonsep emosi tanpa gambar dan 10 soal leksem berkonsep emosi tanpa gambar. Masing-masing soal leksem yang berkonsep abstrak tanpa dan dengan gambar, maupun soal leksem yang berkonsep emosi tanpa dan dengan gambar menyajikan leksemleksem yang sama (lihat lampiran). Hal ini bertujuan untuk mengetahui pengaruh gambar (acuan) dalam proses pemahaman informan terhadap leksem-leksem tersebut.

Leksem-leksem yang digunakan dalam soal adalah leksem-leksem berkonsep emosi dan abstrak yang dipilih secara acak dengan pertimbangan bahwa leksem-leksem tersebut adalah leksem-leksem umum yang dipahami oleh banyak orang. Berikut adalah daftar leksem-leksem yang digunakan dalam soal;

Instrumen kedua adalah rubrik penilaian untuk mengolah data yang didapatkan dari jawaban informan terhadap instrumen pertama. Rubrik penilaian tersebut terdiri dari dua indikator, yaitu indikator ketepatan informan dalam mendefinisikan atau mengartikan leksem dan indikator ketepatan informan dalam menggunakan leksem tersebut dalam konteks kalimat sebagaimana ditampilkan dalam tabel. 2 di bawah ini.

Tabel 1. Daftar Leksem yang Diujikan

\begin{tabular}{|l|c|c|}
\hline No. & Leksem abstrak & Leksem emosi \\
\hline 1. & Kebenaran & Senang \\
\hline 2. & Keadilan & Marah \\
\hline 3. & Rukun & Bosan \\
\hline 4. & Damai & Sedih \\
\hline 5. & Keberagaman & Benci \\
\hline 6. & Hakut \\
\hline 7. & Kewajiban & Malu \\
\hline 8. & Toleransi & Kecewa \\
\hline 9. & Persatuan & Gelisah \\
\hline 10. & Perjuangan & Penasaran \\
\hline
\end{tabular}

\section{Hasil Penelitian}

\subsection{Kelompok SMA/SMAK}

Informan dalam kelompok SMA/SMK berjumlah 7 orang terdiri dari 4 orang informan laki-laki dan 3 orang informan perempuan. Data dari masing-masing informan direkapitulasi

Cite this as:

Alies P. Lintangsari, Wahyu Widodo. Tingkat Pemahaman Arti Leksikal pada Leksem yang Berkonsep Abstrak dan Emosi oleh Penyandang Tunarungu (IJDS).2017: Vol. 4(1): PP.35-44. 
dalam tabel di bawah ini. Hal ini dilakukan untuk memudahkan proses analisis.

Tabel 2. Rekapitulasi Nilai Kelompok SMA/SMAK

mendapatkan nilai lebih jelek pada soal A/TG

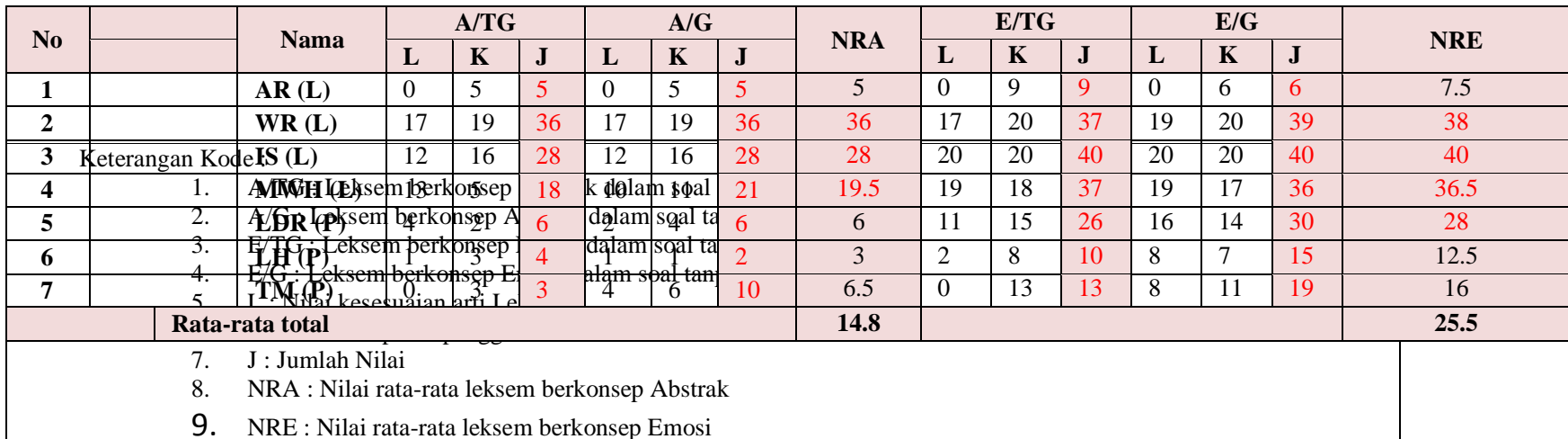

\section{Pemahaman Leksem Berkonsep Abstra pada Kelompok SMA/SMK}

Pemahaman leksem berkonsep abstrak pada kelompok SMA/SMK ditampilkan dalam bentuk diagram di bawah ini untuk kemudian dijelaskan secara deskriptif. Batang A/TG bewarna biru adalah nilai informan saat mengerjakan soal tanpa gambar, sedangkan batang $\mathrm{A} / \mathrm{G}$ berwarna merah adalah nilai informan saat mengerjakan soal dengan gambar. Pengaruh acuan (gambar) pada pemahaman leksem berkonsep abstrak dapat dilihat melalui diagram 1 .

Berdasarkan diagram di atas, temuan terkait pengaruh acuan (gambar) terhadap pemahaman informan terhadap leksem berkonsep abstrak dan emosi sangat bervariasi. Dalam hal pemahaman leksem berkonsep abstrak, didapatkan hasil bahwa sejumlah 4 orang informan tidak terpengaruh oleh acuan dalam memahami leksem berkonsep abstrak. Kesimpulan ini merujuk pada informan yang nilainya sama antara soal A/TG dan soal A/G. Sementara itu, 3 orang informan dalam kelompok SMA terpengaruh oleh acuan (gambar) dengan efek yang berbeda. 2 orang informan mendapatkan nilai lebih baik pada soal $\mathrm{A} / \mathrm{TG}$ daripada soal $\mathrm{A} / \mathrm{G}$ yang menandakan bahwa acuan (gambar) membantu pemahaman informan menjadi lebih baik, tetapi ada 1 orang informan yang

Cite this as:

Alies P. Lintangsari, Wahyu Widodo. Tingkat Pemahaman Arti Leksikal pada Leksem yang Berkonsep Abstrak dan Emosi oleh Penyandang Tunarungu (IJDS).2017: Vol. 4(1): PP.35-44. daripada soal $\mathrm{A} / \mathrm{G}$, hal ini menandakan bahwa acuan (gambar) ternyata dapat memberikaninterpretasi yang berbeda dan juga memberikan kebimbangan pada informan sehingga mempengaruhi informan dalam memahami leksem berkonsep abstrak.

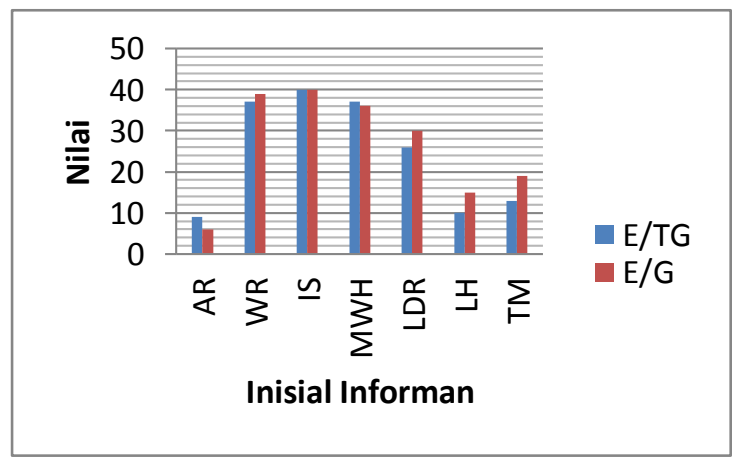

Secara keseluruhan, hanya 3 orang informan yang mendapatkan nilai diatas ratarata, yaitu informan dengan inisial WRP, IS, dan MWH (lihat tabel 4). Dari temuan ini dapat ditarik kesimpulan bahwa acuan (gambar) yang mewakili leksem berkonsep abstrak tidak sepenuhnya dapat membantu informan dalam memahami arti leksem dan penggunaannya dalam kalimat. Hal ini dikarenakan acuan (gambar) yang mewakili leksem berkonsep abstrak tidak bisa sepenuhnya memberikan ketepatan dalam menginterpretasikan makna leksem berkonsep abstrak. Contohnya pada leksem rukun dan keberagaman, sejumlah informan memahami leksem rukun sebagai 
dasar agama Islam, yaitu Rukun Iman dan Rukun Islam, sedangkan keberagaman dipahami sebagai agama dalam soal A/TG. Ketika informan diberikan soal A/G dimana leksem rukun dan keberagaman diwakili oleh gambar dan tulisan sebagaimana tampak dalam gambar 1, informan mengosongkan jawabannya. Hal ini mengindikasikan bahwa acuan (gambar) memberikan interpretasi baru akan makna leksem rukun dan keberagaman yang membuat informan kebingungan sehingga tidak menjawab soal tersebut.

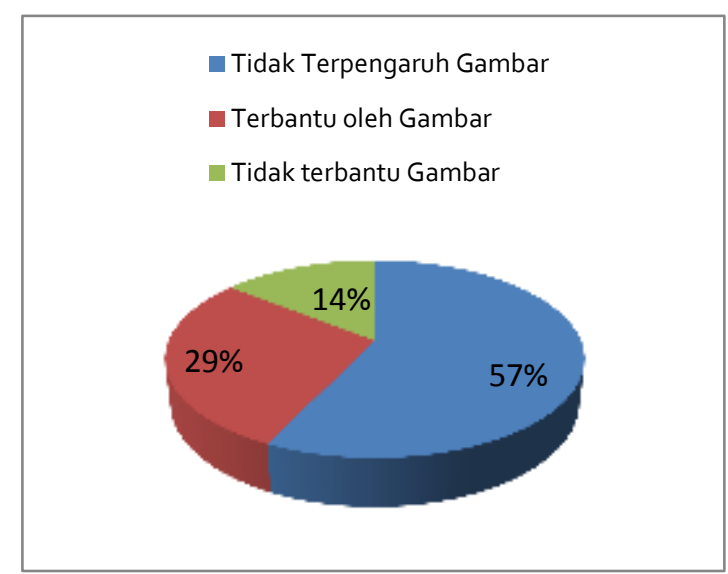

Gambar 2. Prosentase Pengaruh Acuan pada Pemahaman Leksem berkonsep Abstrak

Berdasarkan temuan diatas dapat ditarik dua kesimpulan: pertama adalah bahwa latar belakang pendidikan menengah atas informan yang berasal dari SMA/SMK tidak mempengaruhi kemampuan informan dalam memahami leksem berkonsep abstrak, hal ini dibuktikan oleh data bahwa dari 7 orang informan hanya 3 orang informan yang mendapatkan nilai di atas rata-rata. Kedua adalah bahwa acuan (gambar) tidak memberikan pengaruh yang signifikan untuk membantu informan dalam memahami makna leksem yang berkonsep abstrak, hal ini dibuktikan oleh data bahwa dari 7 orang informan hanya 2 orang saja yang mendapatkan pemahaman lebih baik setelah mengerjakan soal dengan bantuan gambar, sisanya sebanyak 5 orang informan (lihat diagram 2) tidak terpengaruh oleh acuan dan 1 orang informan (lihat diagram 2) tidak terbantu dengan adanya acuan (gambar).

Pemahaman Leksem Berkonsep Emosi pada Kelompok SMA/SMK

Cite this as:

Alies P. Lintangsari, Wahyu Widodo. Tingkat Pemahaman Arti Leksikal pada Leksem yang Berkonsep Abstrak dan Emosi oleh Penyandang Tunarungu (IJDS).2017: Vol. 4(1): PP.35-44.
Pemahaman leksem berkonsep emosi pada kelompok SMA/SMK ditampilkan dalam bentuk diagram di bawah ini untuk kemudian dijelaskan secara deskriptif. Batang E/TG berwarna biru adalah nilai informan saat mengerjakan soal leksem berkonsep emosi tanpa gambar, sedangkan batang E/G berwarna merah adalah nilai informan saat mengerjakan soal leksem berkonsep emosi dengan gambar. Pengaruh acuan (gambar) pada pemahaman leksem berkonsep emosi dapat dilihat melalui diagram berikut ini.

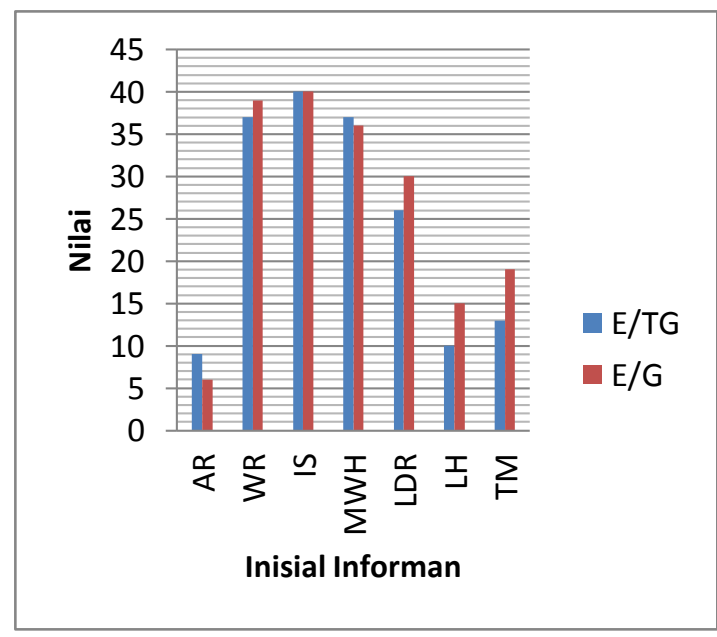

Gambar 3. Nilai Informan pada soal Leksem Berkonsep Emosi

Sebagaimana tersaji dalam diagram 2, hanya ada 1 informan yang tidak terpengaruh acuan (gambar) yaitu infoman IS dikarenakan nilai soal E/TG dan soal E/G sama. Sementara itu, ada 4 orang informan yang mendapatkan nilai lebih baik pada soal E/G daripada soal E/TG yang memberikan kesimpulan bahwa acuan (gambar) berperan dalam membantu informan untuk memahami makna leksem berkonsep emosi. Sedangkan 2 orang informan mendapatkan nilai lebih jelek pada soal E/G daripada soal E/TG.

Apabila melihat perbandingan nilai ratarata pada soal berkonsep abstrak dan soal berkonsep emosi, dapat dilihat dalam tabel 4 bahwa nilai rata-rata soal leksem berkonsep abstrak $(14,8)$ lebih rendah daripada nilai ratarata soal leksem berkonsep emosi $(25,5)$. Berdasarkan temuan ini, dapat ditarik kesimpulan bahwa leksem berkonsep emosi lebih mudah dipahami oleh informan daripada leksem berkonsep abstrak. Hal ini dikarenakan leksem berkonsep emosi memiliki acuan yang lebih konkret daripada leksem berkonsep 
abstrak. Selain itu, leksem emosi mampu diekspresikan dengan berbagai bentuk yang mampu diindra, misalnya, marah dengan pipi merah. Senyum dengan sumringahnya wajah. Berdasarkan diagram di atas, dapat disimpulkan bahwa acuan (gambar) berperan dalam membantu informan untuk memahami leksem berkonsep emosi, sebagaimana terlihat dalam diagram lingkaran di bawah ini bahwa $57 \%$ dari total informan terbantu oleh adanya acuan (gambar) dalam memahami makna leksem berkonsep emosi.

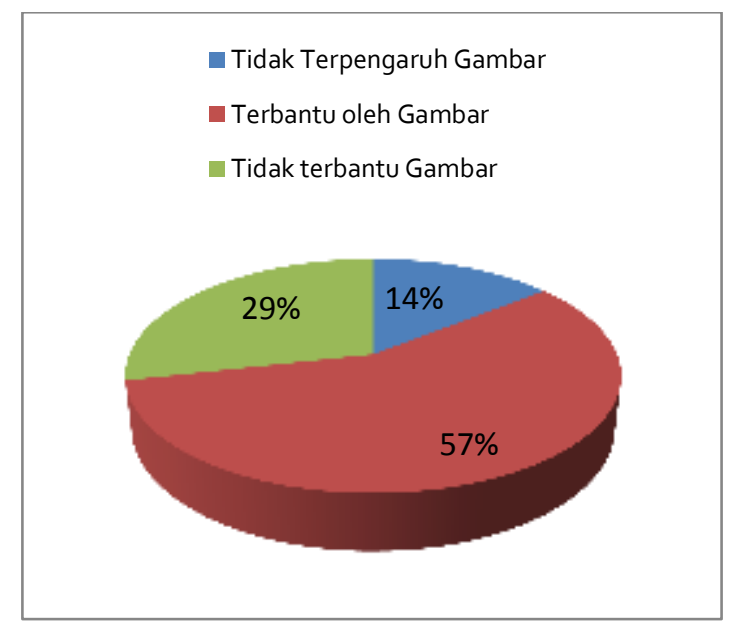

Diagram 4. Persentase Pengaruh Acuan pada Pemahaman Leksem berkonsep Emosi

Kesimpulan yang dapat diambil dari temuan ini: pertama adalah bahwa latar belakang pendidikan menengah atas informan yang berasal dari SMA/SMK tidak mempengaruhi kemampuan informan dalam memahami leksem berkonsep emosi, tetapi pemahaman informan pada leksem berkonsep emosi lebih baik daripada pemahaman informan pada leksem berkonsep abstrak yang dapat dibuktikan dari nilai rata-rata informan pada soal leksem berkonsep emosi lebih tinggi daripada soal leksem berkonsep abstak (lihat tabel 4). Kedua adalah acuan (gambar) berperan dalam membantu pemahaman informan dalam memahami leksem berkonsep emosi yang dibuktikan bahwa 57\% (sebanyak 4 orang) informan yang mendapatkan nilai lebih baik di soal E/TG daripada soal E/G.

\subsection{Kelompok SMALB}

Informan dalam kelompok SMALB berjumlah 7 orang terdiri dari 5 orang informan laki-laki dan 2 orang informan perempuan. Data dari masing-masing informan direkapitulasi dalam tabel di bawah ini untuk memudahkan proses analisis.

Pembahasan selanjutnya dipaparkan dalam sub bab 4.2.1 untuk pembahasan pada pemahaman leksem yang berkonsep abstrak, dan subbab 4.2.2 untuk pembahasan pada pemahaman leksem yang berkonsep emosi

\section{Pemahaman Leksem Berkonsep Abstrak pada Kelompok SMALB}

Pemahaman leksem berkonsep abstrak pada kelompok SMALB ditampilkan dalam bentuk diagram di bawah ini untuk kemudian dijelaskan secara deskriptif. Batang A/TG berwarna biru adalah nilai informan saat mengerjakan soal tanpa gambar, sedangkan batang $\mathrm{A} / \mathrm{G}$ berwarna merah adalah nilai informan saat mengerjakan soal dengan gambar. Pengaruh acuan (gambar) pada pemahaman leksem berkonsep abstrak dapat dilihat melalui diagram dengan membandingkan nilai soal A/TG dan soal A/G

Tabel 3. Rekapitulasi Nilai Kelompok SMALB

\begin{tabular}{|c|c|c|c|c|c|c|c|c|c|c|c|c|c|c|c|}
\hline \multirow{2}{*}{ No } & \multirow{2}{*}{ Nama } & \multicolumn{3}{|c|}{ A/TG } & \multicolumn{3}{|c|}{ A/G } & \multirow{2}{*}{ NRA } & \multicolumn{3}{|c|}{ E/TG } & \multicolumn{3}{|c|}{ E/G } & \multirow{2}{*}{ NRE } \\
\hline & & $\mathbf{L}$ & $\mathbf{K}$ & $\mathbf{J}$ & $\mathbf{L}$ & $\mathbf{K}$ & $\mathbf{J}$ & & $\mathbf{L}$ & $\mathrm{K}$ & $\mathbf{J}$ & $\mathbf{L}$ & $\mathrm{K}$ & $\mathbf{J}$ & \\
\hline 1 & AWU (L) & 10 & 4 & 14 & 12 & 5 & 17 & 15 & 11 & 18 & 28 & 15 & 19 & 34 & 31 \\
\hline 2 & WD (P) & 0 & 0 & 0 & 0 & 1 & 1 & 1.5 & 2 & 11 & 13 & 2 & 12 & 14 & 12.5 \\
\hline 3 & DAK (L) & 3 & 0 & 3 & 1 & 0 & 1 & 1.5 & 3 & 4 & 7 & 3 & 6 & 9 & 8 \\
\hline 4 & JM (L) & 0 & 0 & 0 & 1 & 1 & 2 & 1 & 5 & 15 & 20 & 3 & 15 & 18 & 19 \\
\hline 5 & $\mathbf{L P}(\mathbf{P})$ & 2 & 5 & 7 & 0 & 3 & 3 & 5 & 5 & 8 & 13 & 6 & 11 & 17 & 15 \\
\hline 6 & MDP (L) & 9 & 10 & 19 & 6 & 11 & 17 & 17.5 & 7 & 17 & 24 & 9 & 14 & 23 & 28 \\
\hline 7 & MA (L) & 0 & 2 & 2 & 0 & 2 & 2 & 2 & 3 & 13 & 16 & 1 & 17 & 18 & 17 \\
\hline \multicolumn{8}{|c|}{ Rata-rata total } & 6.2 & & & & & & & 18.6 \\
\hline
\end{tabular}



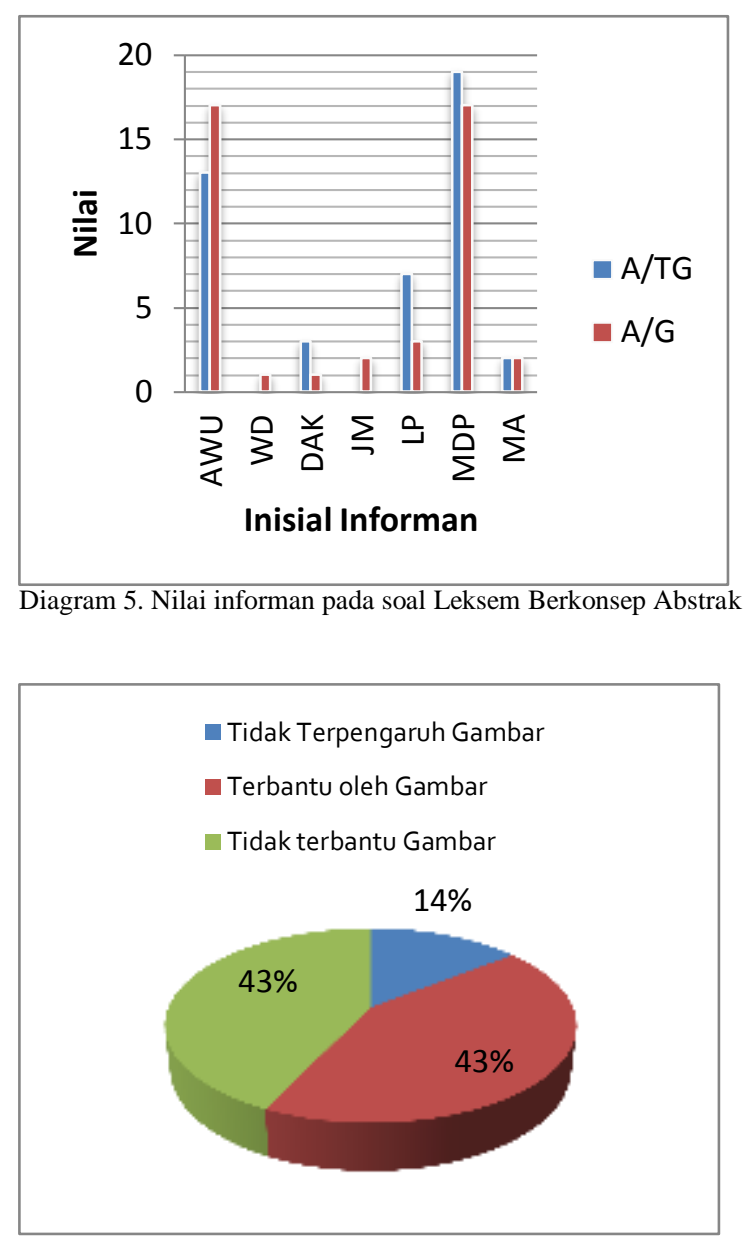

Diagram 6. Persentase Pengaruh Acuan pada Pemahaman Leksem berkonsep Abstrak

Pada informan kelompok sekolah SMALB, terdapat 1 orang yang tidak terpengaruh oleh acuan (gambar), hal ini terlihat dari nilai yang didapatkan informan MA sama antara nilai soal A/G dan soal A/TG. Sementara itu, 6 orang lainnya terpengaruh oleh acuan (gambar), 3 orang informan (AWU, WD dan JM) terpengaruh oleh acuan sehingga mereka mendapatkan pemahaman yang lebih baik tentang makna leksem yang berkonsep abstrak pada soal A/G, tetapi 3 orang lainnya terpengaruh oleh acuan dalam hal yang berbeda. Acuan memberikan interpretasi yang berbeda bagi mereka sehingga mereka menjadi bingung yang menyebabkan mereka tidak menjawab soal $\mathrm{A} / \mathrm{G}$ yang semula pada soal A/TG mereka menjawabnya, atau mereka menjawab jawaban yang berbeda antara jawaban pada soal A/TG dan A/G sehingga jawaban mereka menjadi salah.
Pada diagram 6 dibawah ini, dapat disimpulkan bahwa acuan tidak berperan dalam membantu informan untuk memahami makna leksem berkonsep abstrak mengingat hanya $29 \%$ ( 2 orang) yang terbantu acuan, sedangkan $57 \%$ (4 orang) informan bahkan memiliki interpretasi berbeda akan acuan yang sebenarnya difungsikan untuk membantu mereka memahami, tetapi berperan sebaliknya,yaitu membingungkan mereka dalam memaknai makna leksem. Hal ini berakibat pada nilai mereka pada soal A/G menjadi lebih rendah daripada nilai mereka pada soal $\mathrm{A} / \mathrm{TG}$ dikarenakan mereka tidak menjawab pertanyaan dan/atau mereka menjawab pertanyaan dengan jawaban yang berbeda dengan jawaban mereka sebelumnya dan jawaban tersebut salah.

Berikut adalah data yang menunjukkan bahwa acuan membantu pemahaman informan terhadap leksem yang berkonsep abstrak:

Tabel 4. Acuan membantu pemahaman

\begin{tabular}{|c|c|c|c|c|}
\hline No. & Informan & Leksem & $\begin{array}{c}\text { Jawaban } \\
\text { soal } \\
\text { A/TG }\end{array}$ & $\begin{array}{c}\text { Jawaban } \\
\text { soal A/G }\end{array}$ \\
\hline 1. & JM & Damai & - & Aman \\
\hline 2. & AWU & Keadilan & - & $\begin{array}{c}\text { seimbang } \\
\text { tidak boleh } \\
\text { tidak sama, } \\
\text { harus } \\
\text { persamaan. }\end{array}$ \\
\hline
\end{tabular}

Sedangkan data yang menunjukkan bahwa acuan memberikan kebingungan pada informan terhadap leksem berkonsep abstrak adalah sebagai berikut.

Tabel 5. Acuan tidak membantu pemahaman

\begin{tabular}{|c|c|c|c|c|}
\hline No. & Informan & Leksem & $\begin{array}{c}\text { Jawaban } \\
\text { soal } \\
\text { A/TG }\end{array}$ & $\begin{array}{l}\text { Jawaban } \\
\text { soal A/G }\end{array}$ \\
\hline 1. & LP & Kebenaran & $\begin{array}{c}\text { Betul- } \\
\text { betul } \\
\text { benar }\end{array}$ & Semangat \\
\hline 2. & MDP & Hak & $\begin{array}{c}\text { Hak } \\
\text { adalah } \\
\text { tidak ada } \\
\text { dipaksa, } \\
\text { masing- } \\
\text { masing } \\
\text { sendiri. }\end{array}$ & $\begin{array}{c}\text { Hak } \\
\text { adalah } \\
\text { bebas dari } \\
\text { salah. }\end{array}$ \\
\hline
\end{tabular}

Kesimpulan dari pembahasan ini adalah bahwa pada leksem berkonsep abstrak, acuan bisa membantu informan untuk memahami leksem berkonsep abstrak dan/atau bahkan sebaliknya. 


\begin{tabular}{|c|c|c|c|c|}
\hline No. & Informan & Leksem & $\begin{array}{c}\text { Jawaban } \\
\text { soal A/TG }\end{array}$ & $\begin{array}{c}\text { Jawaban } \\
\text { soal A/G }\end{array}$ \\
\hline KelompokLSMAALE & Sedih & Sakit Hati \\
\hline
\end{tabular}

2. Pemakkman lekksem berkonsep emosirapada
kelompokPSMAIGgrad itampifimasi dalam Segahtuk diagram di bawah ini tilutuk kemudian dijelaskan secara deskriptif. Batang E/TG bewarna biru adalah nilai informan saat mengerjakan soal leksem berkonsep emosi tanpa gambar, sedangkan batang E/G bewarna merah adalah nilai informan saat mengerjakan soal leksem berkonsep emosi dengan gambar. Pengaruh acuan (gambar) pada pemahaman leksem berkonsep emosi dapat dilihat melalui diagram 7 dibawah ini dengan membandingkan nilai soal E/TG dan soal E/G.

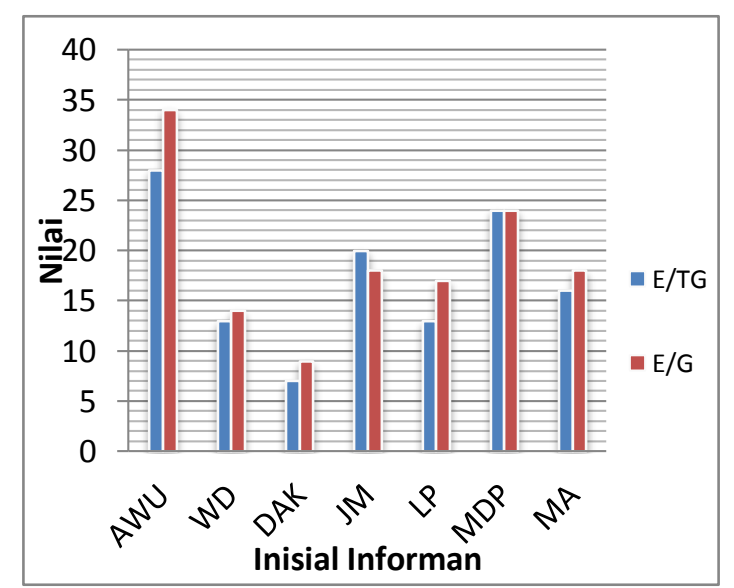

Diagram 7. Nilai informan pada soal Leksem Berkonsep Emosi

Berdasarkan diagram 7, terdapat 1 informan yang tidak terpengaruh acuan yaitu MDP, sedangkan 5 orang informan terbantu untuk memahami leksem berkonsep emosi yatu AWU, WD, DAK, LP dan MA. Sedangkan 1 informan,yaitu JM tidak terbantu dengan adanya acuan hal ini dibuktikan dengan nilai yang didapatkan JM pada soal E/G lebih rendah daripada nilai pada soal E/TG.

Pada diagram di bawah ini dapat disimpulkan bahwa acuan berperan dalam membantu informan untuk memahami leksem berkonsep emosi sebagaimana terlihat bahwa sebesar $72 \%$ (5 orang informan) terbantu dengan adanya acuan, sedangkan $14 \%$ (1 orang informan) tidak terbantu, dan $14 \%$ (1 orang) tidak terpengaruh dengan adanya acuan (gambar).

Tabel 6. Acuan membantu pemahaman
Diagram 8. Persentase Pengaruh Acuan pada Pemahaman Leksem berkonsep Emosi

Berikut adalah data yang menunjukkan bahwa acuan membantu pemahaman informan terhadap leksem yang berkonsep emosi: Sedangkan data yang menunjukkan bahwa acuan memberikan kebingungan pada informan terhadap leksem berkonsep emosi adalah sebagai berikut.

Tabel 7. Acuan tidak membantu pemahaman

Kesimpulan dari pembahasan ini adalah bahwa pada leksem berkonsep emosi, acuan memberikan peran penting dalam membantu informan memahami leksem emosi. Hal ini dikarenakan acuan yang mengacu pada leksem emosi lebih tampak jelas dan lebih universal sehingga sedikit kemungkinan untuk salah

\begin{tabular}{|c|c|c|c|c|}
\hline No. & Informan & Leksem & $\begin{array}{c}\text { Jawaban } \\
\text { soal } \\
\text { A/TG }\end{array}$ & $\begin{array}{c}\text { Jawaban } \\
\text { soal A/G }\end{array}$ \\
\hline 1. & JM & Gelisah & Galau & $\begin{array}{c}\text { Tidak } \\
\text { dijawab } \\
\text { Pikir }\end{array}$ \\
\hline
\end{tabular}

diinterpretasikan daripada acuan yang mengacu pada leksem abstrak. Walaupun begitu, masih ditemukan 1 orang informan yang kurang benar dalam menginterpretasikan acuan pada leksem emosi sehingga jawaban menjadi salah (lihat tabel 9.).

\section{Kesimpulan}

Sebagaimana telah dipaparkan dalam bab 4, beberapa kesimpulan dapat diambil dari penelitian ini sebagaimana berikut :

Berdasarkan temuan dalam data informan kelompok SMA maupun informan kelompok SMALB, didapatkan hasil bahwa acuan (gambar) tidak terlalu berperan dalam membantu informan untuk memahami arti

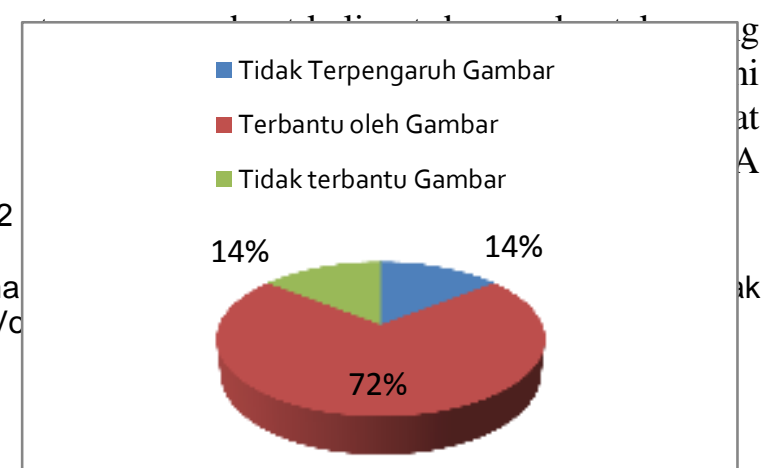

Cite this as:

Alies P. Lintangsari, Wahyu Widodo. Tingkat Pemahama dan Emosi oleh Penyandang Tunarungu (IJDS).2017: Vo 
tidak terpengaruh oleh acuan, dan sejumlah $43 \%$ (lihat diagram 7), informan pada kelompok SMALB tidak terbantu acuan serta 14\% informan pada kelompok SMALB tidak terpengaruh acuan. Hal ini disebabkan karena acuan (gambar) pada leksem berkonsep abstrak tidak langsung mengacu pada makna leksem tersebut sehingga memungkinkan adanya perbedaan interpretasi antara acuan dan makna leksem.

Berbeda dengan pengaruh acuan pada leksem berkonsep abstrak yang tidak terlalu memberikan manfaat bagi pemahaman informan, acuan pada leksem berkonsep emosi berperan penting dalam membantu pemahaman informan terhadap makna leksem emosi. Berdasarkan data diatas (lihat diagram 4) ditemukan bahwa 57\% informan terbantu dengan adanya acuan (gambar) pada informan kelompok SMA dan sebesar 72\% informan terbantu memahami makna leksem emosi pada informan kelompok SMALB.

Pengelompokan informan menjadi dua kelompok yaitu kelompok SMA dan kelompok SMALB memberikan kesimpulan bahwa kemampuan informan dari kelompok SMA lebih dalam memahami kedua leksem baik abstrak maupun emosi daripada informan dari kelompok SMALB sebagaimana terlihat dari nilai rata-rata (lihat tabel 4 dan 5). Berdasarkan data, nilai rata-rata informan kelompok SMA adalah 14.8 untuk leksem berkonsep abstrak dan 25.5 untuk leksem berkonsep emosi, sedangkan nilai rata-rata informan kelompok SMALB adalah 6.2 untuk leksem berkonsep abstrak dan 18.6 untuk leksem berkonsep emosi.

Nilai rata-rata antara leksem berkonsep abstrak dan leksem berkonsep emosi, baik dalam kelompok SMA maupun kelompok SMALB, dapat disimpulkan bahwa semua informan lebih mudah memahami leksem emosi daripada leksem berkonsep abstrak. Hal ini disebabkan karena acuan dalam leksem emosi lebih jelas sehingga kesalahan interpretasi lebih sedikit daripada pada leksem berkonsep abstrak.

Secara umum, dapat disimpulkan bahwa Tunarungu membutuhkan acuan untuk memahami leksem berkonsep abstrak maupun emosi. Untuk leksem berkonsep abstrak, acuan sebaiknya diberikan secara kontekstual, acuan dalam bentuk gambar saja tidak cukup memberikan informasi akan ketepatan interpretasi makna oleh Tunarungu. Berbeda dengan leksem berkonsep emosi yang acuannya lebih bersifat jelas salah satunya melalui ekspresi wajah sehingga kesalahan interpretasi lebih minimal daripada pada leksem berkonsep abstrak.

Penelitian berjudul "Tingkat Pemahaman Arti Leksikal pada Leksem Berkonsep Abstrak dan Emosi oleh Penyandang Tunarungu" ini diharapkan mampu memberikan informasi dan pengetahuan bagi pihak terkait seperti peneliti yang tertarik dengan Ketunarunguan dan makna leksikal, pengajar bahasa, khususnya bagi anak Tunarungu dan pihak-pihak terkait lainnya. Saran yang dapat kami berikan selaku peneliti dalam penelitian ini adalah bagi penagajaran bahasa khususnya pemaknaan leksem berkonsep abstrak dan berkonsep emosi, perlu dilengkapi dengan media pembelajaran yang memadai yang dapat berfungsi sebagai acuan. Khususnya acuan untuk menjelaskan leksem berkonsep abstrak sebaiknya acuan yang jelas dan rinci, misalnya acuan menggunakan komik atau gambar bergerak.

\section{DAFTAR PUSTAKA}

Johnston \& Schembri. (2007). Australian Sign Language: An Introduction to Lingusitics. Cambridge University Press.

Kadarisman, A. Effendi. 2009. Mengurai Bahasa, Menyibak Budaya. Malang: UIN Maliki Press.

Lintangsari, Alies Poetri. (2014). Identifikasi Kebutuhan Mahasiswa Tuli dalam Pembelajaran Bahasa Tulis. Indonesian Journal of Disability Studies. PSLD Universitas Brawijaya.

Soenjono, Dardjowidjojo.2009. Psikolinguistik. Jakarta: Yayasan Obor Indonesia.

Subroto, Edi.2002."Ihwal Relasi Makna: Beberapa Kasus dalam Bahasa Indonesia" dalam Telaah Bahasa dan Sastra. Jakarta:Yayasan Obor dan Pusat Bahasa.

Subroto, Edi. 2011. Pengantar Studi Semantik. Surakarta : CakrawalaMedia

Suwiryo, Adhika Irlang. (2014). Mouth Gesture pada Bahasa Isyarat Jakarta dan Bahasa Isyarat Yogyakarta: Studi Awal. Prosiding Seminar 
Internasional Semantik, Pragmatik, dan Kebudayaan. Lembaga Riset Bahasa Isyarat Fakultas Ilmu Pengetahuan Budaya. Universitas Indonesia

Woodward, James. (2014). Some Universal and Unique Characteristics of Human Languages from the perspective of Sign Linguistics. Tayangan powerpoint dipresentasikan pada Seminar Internasional Semiotik, Pragmatik, dan Kebudayaan. Fakultas Ilmu Pengetahuan Budaya Universitas Indonesia. 